JURNAL NOMINAL / VOLUME IV NOMOR 1 / TAHUN 2015

\title{
FAKTOR-FAKTOR YANG MEMPENGARUHI KEBIJAKAN DIVIDEN PADA SEKTOR INDUSTRI BARANG KONSUMSI
}

\author{
Pujiati \\ Alumni Prodi Akuntansi Universitas Negeri Yogyakarta \\ pujiatids@gmail.com
}

\begin{abstract}
Abstrak: Faktor-Faktor yang Mempengaruhi Kebijakan Dividen pada Sektor Industri Barang Konsumsi. Penelitian ini bertujuan untuk mengetahui pengaruh variabel kepemilikan manajerial, kepemilikan institusional, dan kesempatan investasi terhadap kebijakan dividen dengan menggunakan likuiditas sebagai variabel pemoderasi pada perusahaan sektor industri barang konsumsi yang terdaftar di Bursa Efek Indonesia periode 2008-2013. Penelitian ini termasuk dalam penelitian asosiatif (hubungan), yaitu penelitian yang bertujuan untuk mengetahui hubungan dua variabel atau lebih. Populasi penelitian ini adalah perusahaan sektor industri barang konsumsi yang terdaftar di Bursa Efek Indonesia periode 2008-2013. Tehnik pengambilan sampel menggunakan purposive sampling. Terdapat 7 perusahaan yang memenuhi kriteria sebagai sampel penelitian sehingga data penelitian berjumlah 42. Hasil penelitian ini adalah kepemilikan manajerial berpengaruh positif tetapi tidak signifikan terhadap kebijakan dividen, kepemilikan institusional berpengaruh positif dan signifikan terhadap kebijakan dividen, kesempatan investasi berpengaruh negatif dan signifikan terhadap kebijakan dividen, likuiditas mampu memoderasi kepemilikan manajerial terhadap kebijakan dividen, likuiditas mampu memoderasi kepemilikan institusional terhadap kebijakan dividen, likuditas tidak mampu memoderasi kesempatan investasi terhadap kebijakan dividen, dan kepemilikan manajerial, kepemilikan institusional, dan kesempatan investasi berpengaruh bersama-sama terhadap kebijakan dividen.
\end{abstract}

Kata kunci: kebijakan dividen, kepemilikan manajerial, kepemilikan institusional, kesempatan investasi

Abstract: Factors Influencing Corporate Dividend Policy of Consumer Goods Industry. The research examines the effect of managerial ownership, institutional ownership, and investment opportunity on dividend policy with liquidity as moderating variable. This study used a sample of consumer goods industry that distribute dividend in the period 2008-2013 are listed on the Indonesia Stock Exchange. Purposive sampling is used as sampling technique. Fourty two firms were used as research data. This research concludes that managerial ownership have positive but not significant influence toward dividend policy and liquidity moderate this influence, institutional ownership have positive and significant influence toward dividend policy and liquidity moderate this influence, investment opportunity have negative and significant influence toward dividend policy and liquidity can't moderate this influence, managerial ownership, institutional ownership, and investment opportunity have significant influence toward dividend policy.

Keywords: dividend policy, managerial ownership, institutional ownership, investment opportunity

\section{PENDAHULUAN}

Wewenang dalam menetapkan

kebijakan dividen merupakan salah satu wewenang yang didelegasikan pemegang saham kepada dewan direksi perusahaan. Keputusan kebijakan dividen merupakan 


\section{JURNAL NOMINAL / VOLUME IV NOMOR 1 / TAHUN 2015}

keputusan tentang jumlah laba saat ini yang akan dibayarkan sebagai dividen daripada laba yang akan ditahan untuk kemudian diinvestasikan kembali dalam perusahaan (Brigham, E.F. dan Houston, J.F, 2011: 27). Perusahaan dalam menetapkan kebijakan dividen harus memperhatikan faktor-faktor yang berpengaruh terhadap kebijakan dividen. Keputusan kebijakan dividen merupakan salah satu cara untuk meningkatkan kesejahteraan para pemegang saham terutama pemegang saham yang berorientasi pada jangka panjang bukan pemegang saham yang berorientasi pada capital gain. Oleh sebab itu, perusahaan akan berusaha meningkatkan pembayaran dividen dari tahun ke tahun (Ratih Fitria Sari, 2010: 20).

Masalah kebijakan dividen berkaitan dengan masalah keagenan. Salah satu pihak yang menentukan kebijakan dividen adalah manajer. Perusahaan sebaiknya menetapkan kebijakan dividen yang rendah agar memiliki sumber dana internal yang relatif lebih murah jika dibandingkan dengan pendanaan melalui utang atau emisi saham baru. Kenyataannya, manajer juga terlibat dalam kepemilikan saham sehingga terkadang menginginkan return dalam bentuk dividen. Perilaku manajer yang menyukai dividen rendah akan berakibat pada laba ditahan yang dimiliki perusahaan menjadi relatif tinggi. Jika manajer menyukai dividen yang besar maka akan berdampak pada sumber dana internal yang dimiliki perusahaan akan relatif rendah. Pada situasi tersebut, jika perusahaan ingin melakukan ekspansi maka akan didanai dari sumber dana eksternal yang relatif mahal, misalnya menggunakan utang. Peningkatan penggunaan utang akan meningkatkan rasio utang yang mengakibatkan risiko kebangkrutan dan financial distress. Keputusan tersebut justru akan menimbulkan konflik baru antara manajer, pemegang saham, dan kreditur sehingga perusahaan harus secara bijak dalam menentukan kebijakan dividen karena masing-masing alternatif keputusan akan memiliki risiko (Easterbrook dalam Kartika Nuringsih, 2005: 105).

Perilaku manajer dapat diawasi oleh pemegang saham dengan mengeluarkan kos pengawasan yang disebut agency cost. Kepemilikan manajerial dipandang dapat mengurangi agency cost apabila porsinya dalam struktur kepemilikan di perusahaan ditingkatkan. Pemberian kesempatan manajer untuk terlibat dalam kepemilikan saham bertujuan untuk menyetarakan kepentingan manajer dengan pemegang saham. Keterlibatan manajer tersebut mendorong manajer untuk bertindak secara hati-hati karena mereka akan turut menanggung konsekuensi atas keputusan yang diambilnya. Selain itu, manajer akan termotivasi untuk meningkatkan kinerjanya dalam mengelola perusahaan (Sisca 


\section{JURNAL NOMINAL / VOLUME IV NOMOR 1 / TAHUN 2015}

Christianty Dewi, 2008: 48). Manajer yang memiliki saham dalam perusahaan yang dipimpin akan mempunyai peran ganda yaitu sebagai manajer sekaligus investor. Posisi manajer sebagai investor lebih menyukai pendapatan dividen yang besar (bird in the hand theory).

Kepemilikan institusional dianggap dapat memonitor kinerja manajemen. Kepemilikan institusional yang tinggi akan menghasilkan upaya-upaya pengawasan yang lebih intensif sehingga dapat membatasi perilaku opportunistic manajer, yaitu manajer melaporkan laba secara oportunis untuk memaksimalkan kepentingan pribadinya Jensen dan Meckling (1976: 372-373). Selain itu, pengawasan yang efektif dari investor institusional akan memaksa manajer untuk mendistribusikan arus kas sebagai dividen. Dividen dapat digunakan sebagai kompensasi investor institusional atas kegiatan pengawasan mereka terhadap manajerial perusahaan (Shleifer, Andrei dan Vishny Robert W, 1986: 478).

Setiap investor pasti mengharapkan pertumbuhan perusahaan agar dapat memperoleh pengembalian seperti yang diinginkan atas partisipasinya dalam bentuk penyertaan saham. Di sisi lain, pihak manajemen akan membatasi arus kas keluar berupa dividen kas yang berjumlah terlalu besar dengan alasan mempertahankan kelangsungan hidup perusahaan, menambah investasi, maupun melunasi utang (Michell Suharli dan Megawati Oktorina, 2005: 288289). Terlebih jika kondisi perusahaan dalam keadaan yang baik, maka pihak manajemen akan cenderung lebih memilih investasi baru daripada membayar dividen bagi pemegang saham dalam jumlah yang tinggi (Michell Suharli, 2007: 12). Oleh karena itu, semakin besar investasi yang dikeluarkan pada periode tertentu maka semakin kecil dividen yang akan dibayarkan.

Likuiditas perusahaan merupakan pertimbangan utama manajer dalam menentukan besaran kebijakan dividen. Bagi perusahaan, dividen merupakan kas keluar sehingga semakin besar posisi kas dan likuiditas perusahaan secara keseluruhan akan semakin besar kemampuan perusahaan untuk membayar dividen. Syarat perjanjian utang sebagai pelindung dalam kesepakatan obligasi atau perjanjian pinjaman sering kali meliputi batasan untuk pembayaran dividen. Batasan tersebut ditentukan oleh pihak pemberi pinjaman untuk menjaga kemampuan perusahaan membayar utang. Ketika larangan tersebut diberlakukan maka akan mempengaruhi kebijakan dividen perusahaan (Van Horne, James C dan Wachowicz, John M, 2007: 282-283) 


\section{JURNAL NOMINAL / VOLUME IV NOMOR 1 / TAHUN 2015}

\section{METODE PENELITIAN}

Jenis Penelitian

Berdasar jenis data dan analisis yang digunakan, penelitian ini termasuk dalam penelitian kuantitatif karena mengacu pada perhitungan data berupa angka.

\section{Waktu dan Tempat Penelitian}

Penelitian ini dilakukan pada perusahaan sektor industri barang konsumsi yang terdaftar di BEI periode 2008-2013. Pengambilan data dilakukan di Bursa Efek Indonesia melalui situs website www.idx.co.id. Waktu penelitian ini dilaksanakan bulan Desember - Maret 2015.

\section{Target/Subjek Penelitian}

Populasi dalam penelitian ini adalah perusahaan sektor industri barang konsumsi yang terdaftar di Bursa Efek Indonesia periode 2008-2013. Metode pengambilan sampel melalui purposive sampling. Berdasarkan kriteria yang telah ditetapkan dengan menggunakan metode purposive sampling, maka terdapat tujuh perusahaan sektor industri barang konsumsi yang terdaftar di Bursa Efek Indonesia selama tahun 2008 sampai dengan tahun 2013 yang dijadikan sampel.

\section{Data, Intrumen, dan Teknik Pengum- pulan}

a) Data

Metode pengumpulan data yang digunakan dalam penelitian ini adalah metode dokumentasi yakni dengan mengumpulkan dokumen secara online dengan mengambil data melalui website resmi Bursa Efek Indonesia.

b) Teknik Analisis Data

1) Uji Statistik Deskriptif

Statistik deskriptif digunakan peneliti untuk memberikan informasi mengenai karakteristikkarakteristik variabel penelitian utama serta demografi jika ada (Indrianto dan Supomo, 2009: 170). Pengukuran yang digunakan adalah nilai minimum, nilai maksimum, rata-rata (mean), dan standar deviasi.

2) Uji Asumsi Klasik

Pengujian asumsi klasik dalam penelitian ini meliputi uji normalitas, uji multikolinearitas, uji autokorelasi, uji heteroskedastisitas, dan uji linearitas.

3) Uji Hipotesis

Dalam penelitian ini, pengujian hipotesis dengan menggunakan analisis regresi linear 


\section{JURNAL NOMINAL / VOLUME IV NOMOR 1 / TAHUN 2015}

sederhana, analisis regresi nilai selisih mutlak, dan analisis regresi linear berganda.

\section{HASIL PENELITIAN DAN}

PEMBAHASAN

Variabel yang diukur dalam penelitian ini diproksikan dengan Kebijakan Dividen (DPR), Kepemilikan Manajerial (MNJR), Kepemilikan Institusional (INST), Kesempatan Investasi (capital expenditur to book value of asset/CAPBVA), dan Likuiditas (CR).

\section{Analisis Statistik Deskriptif}

Hasil statistik deskriptif dari variabel tersebut dapat diamati pada tabel 1 sebagai berikut:

Tabel 1. Hasil Stastistik Deskriptif

\begin{tabular}{lrrrcc}
\hline & & Min & Max & & Std. \\
& & imu & imu & & Deviati \\
& $\mathrm{N}$ & $\mathrm{m}$ & $\mathrm{m}$ & Mean & on \\
\hline DP & 42 & 0,10 & 0,92 & 0,48814 & 0,22596 \\
$\mathrm{R}$ & & 791 & 56 & & \\
\hline MN & 42 & 0,00 & 0,17 & 0,00308 & 0,00428 \\
JR & & 001 & 44 & & \\
\hline INS & 42 & 0,24 & 0,96 & 0,74187 & 0,17022 \\
T & & 132 & 09 & & \\
\hline CA & 42 & - & 0,44 & 0,03509 & 0,06993 \\
PB & & 0,02 & 89 & & \\
VA & & 65 & & & \\
\hline CR & 42 & 0,88 & 11,7 & 3,73469 & 1,56970 \\
& & 077 & 43 & & \\
\hline
\end{tabular}

\section{Uji Asumsi Klasik}

Berikut adalah persamaan regresi dalam penelitian ini:

1: $\mathrm{Y}=\alpha+\beta_{1} \mathrm{MNJR}+\varepsilon$

2: $\mathrm{Y}=\alpha+\beta_{2} \mathrm{INST}+\varepsilon$

3: $\mathrm{Y}=\alpha+\beta_{3}$ CAPBVA $+\varepsilon$

4: $\mathrm{Y}=\alpha+\beta_{1} \mathrm{ZMNJR}+\beta_{4} \mathrm{ZCR}+\beta_{5}$

AbsMNJR $-\mathrm{CR}+\varepsilon$

5: Y $=\alpha+\beta_{2} \mathrm{ZINST}+\beta_{4} \mathrm{ZCR}+\beta_{6}$

AbsINST $-\mathrm{CR}+\varepsilon$

6: Y $=\alpha+\beta_{3}$ ZCAPBVA $+\beta_{4} \mathrm{ZCR}+\beta_{7}$

AbsCAPBVA $-\mathrm{CR}+\varepsilon$

7: $\mathrm{Y}=\alpha+\beta_{1}$ MNJR $+\beta_{2}$ INST $+\beta_{3}$

$\mathrm{CAPBVA}+\varepsilon$

\section{Hasil Uji Normalitas}

Berdasarkan hasil uji normalitas menggunakan uji Kolmogorov-Smirnov pada tabel 2 menunjukkan hubungan yang normal. Besarnya nilai KolmogorovSmirnov (K-S) untuk Unstandardized Residual adalah 0,701, 0,732, 1,095, dan 0,794 dengan probabilitas signifikansi $0,710,0,658,0,182$, dan 0,554 berada di atas $\alpha=0,05$. Hal ini berarti $\left(\mathrm{H}_{0}\right)$ diterima dan $\left(\mathrm{H}_{\mathrm{a}}\right)$ ditolak. Hasil uji normalitas atas seluruh model regresi di atas diamati pada tabel 2 sebagai berikut: 
JURNAL NOMINAL / VOLUME IV NOMOR 1 / TAHUN 2015

Tabel 2. Ringkasan Hasil Uji Normalitas

\begin{tabular}{|c|c|c|c|}
\hline & ZCR & & \\
\hline \multirow[t]{6}{*}{6} & Zscore & 0,183 & 5,457 \\
\hline & (CAPBVA) & & \\
\hline & Zscore & 0,330 & 3,033 \\
\hline & (CR) & & \\
\hline & AbsCAPB & 0,163 & 6,144 \\
\hline & VA_CR & & \\
\hline
\end{tabular}

Hasil uji multikolinearitas pada tabel 3

\section{Hasil Uji Multikolinearitas}

Hasil uji multikolinearitas atas seluruh model regresi di atas diamati pada tabel 3 sebagai berikut:

Tabel 3. Ringkasan

Hasil

Uji

Multikolinearitas

\begin{tabular}{lccc}
\hline Persa- & Model & Tole- & VIF \\
maan & & rance &
\end{tabular}

Regresi

\begin{tabular}{llll}
\hline $1,2,3,7$ & MNJR & 0,958 & 1,044 \\
\cline { 2 - 4 } & INST & 0,951 & 1,052 \\
\cline { 2 - 4 } & CAPBVA & 0,976 & 1,025 \\
\hline 4 & Zscore & 0,586 & 1,707 \\
& $($ MNJR $)$ & & \\
\cline { 2 - 4 } & Zscore & 0,498 & 2,006 \\
& $($ CR $)$ & & \\
\cline { 2 - 4 } & AbsMNJR_ & 0,350 & 2,855 \\
& CR & & \\
\hline 5 & Zscore & 0,865 & 1,156 \\
& $($ INST) & & \\
\hline & Zscore & 0,859 & 1,164 \\
& $($ CR $)$ & & \\
\hline & AbsINST_ & 0,751 & 1,331 \\
\hline
\end{tabular}
menunjukkan bahwa nilai Tolerance yang dimiliki oleh seluruh variabel independen tersebut di atas 0,1 yang berarti tidak ada korelasi antarvariabel independen yang nilainya lebih dari 95\%. Hasil perhitungan nilai Variance Inflation Factor (VIF) juga menunjukkan hal yang sama bahwa nilai VIF yang dimiliki oleh seluruh variabel independen adalah di bawah 10. Dengan demikian dapat disimpulkan bahwa model regresi penelitian ini tidak terjadi multikolinearitas dan model regresi layak untuk digunakan.

\section{Hasil Uji Autokorelasi}

Hasil uji autokorelasi atas seluruh model regresi di atas diamati pada tabel 4 sebagai berikut: 
JURNAL NOMINAL / VOLUME IV NOMOR 1 / TAHUN 2015

Tabel 4. Ringkasan Hasil Uji Autokorelasi

\begin{tabular}{lcrrr}
\hline \multicolumn{5}{c}{ Unstandardized Residual } \\
Persa- & $1,2,3$, & & & \\
maan & 7 & 4 & 5 & 6 \\
Regresi & & & & \\
\hline Test & - & - & - & - \\
Value & 0,034 & 0,022 & 0,043 & 0,032 \\
& 1 & 7 & 4 & 1 \\
\hline Assymp & 0,274 & 0,27 & 0,63 & 0,27 \\
Sig & & 4 & 9 & 4 \\
(2- & & & & \\
tailed) & & & &
\end{tabular}

Hasil uji autokorelasi pada tabel 4 menunjukkan bahwa nilai Test adalah $0,0341,-0,0227,-0,0434$, dan $-0,0321$ dengan probabilitas $0,274,0,274,0,639$, dan 0,274 lebih besar dari tingkat signifikansi yang ditetapkan sebelumnya (5\%). Dengan demikian hipotesis Ho diterima sehingga dapat disimpulkan bahwa residual random atau tidak terjadi autokorelasi antarnilai residual.

\section{Hasi Uji Heteroskedastisitas}

Hasil uji heterokedastisitas melalui uji Glejser pada tabel 5 menunjukkan hasil bahwa tidak ada satu pun variabel independen yang signifikan secara statistik mempengaruhi variabel dependen nilai absolute Ut (AbsUt). Hasil probabilitas seluruh variabel tersebut berada di atas tingkat kepercayaan 5\%. Dengan demikian dapat disimpulkan bahwa model regresi penelitian ini tidak mengandung adanya heteroskedastisitas. Hasil uji heteroskedastisitas atas seluruh model regresi di atas diamati pada tabel 5 sebagai berikut:

Tabel 5. Ringkasan Hasil Uji Heteroskedastisitas

\begin{tabular}{lccc}
\hline Persa- & Model & Tole- & VIF \\
maan & & rance &
\end{tabular}

Regresi

\begin{tabular}{|c|c|c|c|}
\hline $1,2,3,7$ & MNJR & 0,576 & 0,568 \\
\hline & INST & $-1,145$ & 0,259 \\
\hline & CAPBVA & $-1,782$ & 0,083 \\
\hline 4 & Zscore & 0,986 & 0,330 \\
\hline & (MNJR) & & \\
\hline & Zscore (CR) & 1,276 & 0,210 \\
\hline & AbsMNJR_ & $-1,758$ & 0,087 \\
\hline & $\mathrm{CR}$ & & \\
\hline 5 & Zscore & $-1,003$ & 0,322 \\
\hline & (INST) & & \\
\hline & Zscore (CR) & 1,376 & 0,177 \\
\hline & AbsINST_Z & $-0,060$ & 0,952 \\
\hline & $\mathrm{CR}$ & & \\
\hline 6 & Zscore & 0,697 & 0,490 \\
\hline & (CAPBVA) & & \\
\hline & Zscore (CR) & 1,971 & 0,056 \\
\hline & AbsCAPBV & $-1,433$ & 0,160 \\
\hline & A_CR & & \\
\hline
\end{tabular}




\section{JURNAL NOMINAL / VOLUME IV NOMOR 1 / TAHUN 2015}

\section{Hasil Uji Linearitas}

Hasil uji linearitas atas seluruh model regresi di atas diamati pada tabel 6 sebagai berikut:

Tabel 6. Ringkasan Hasil Uji Linearitas

\begin{tabular}{lccc}
\hline Model & $\mathrm{R}^{2}$ & $\mathrm{c}^{2}$ & $\mathrm{c}^{2}$ \\
& & hitung & tabel \\
MNJR2, INST2, & 0,005 & 0,021 & 58,11 \\
CAPBVA2 & & & \\
\hline ZMNJR2, ZCR2, 0,060 & 2,52 & 58,11 \\
AbsMNJR_CR2 & & & \\
\hline ZINST2, ZCR2, 0,117 & 4,914 & 58,11 \\
AbsINST_CR2 & & & \\
\hline ZCAPBVA2, & 0,164 & 6,888 & 58,11 \\
ZCR2, & & \\
AbsCAPBVA_CR2 & & &
\end{tabular}

Hasil uji linearitas melalui uji Lagrange Multiplier pada tabel 6 menunjukkan bahwa nilai $c^{2}$ hitung dari seuluruh model lebih kecil dari $\mathrm{c}^{2}$ tabel maka dapat disimpulkan bahwa model yang benar adalah model linear.

\section{Uji Hipotesis}

Analisis statistik yang digunakan dalam penelitian ini adalah analisis regresi. Uji regresi baik uji t, uji nilai selisih mutlak, maupun uji $\mathrm{F}$ sangat dipengaruhi oleh nilai residual yang mengikuti distribusi normal sehingga apabila asumsi ini menyimpang dari distribusi normal akan menyebabkan uji statistik menjadi tidak valid.

\section{Hasil Uji Hipotesis Pertama}

Tabel 7. Ringkasan Hasil Uji Hipotesis

Pertama

\begin{tabular}{cccccc}
\hline Varia & Kons- & Koefi- & $\mathrm{r}^{2}$ & $\mathrm{t}$ & Sig. \\
bel & tanta & sien & \multicolumn{3}{c}{ hitung } \\
& & Re- & & & \\
& & gresi & & & \\
& & & & \\
MNJR & 0,465 & 1,481 & 0,065 & 1,666 & 0,104 \\
\hline
\end{tabular}

Berdasarkan tabel 7 di atas, persamaan regresi sebagai berikut:

$\mathrm{DPR}=0,465+1,481 \mathrm{MNJR}$

Berdasarkan tabel 7 dapat dilihat bahwa nilai thitung sebesar 1,666 jika dibandingkan dengan $t_{\text {tabel }}$ pada tingkat signifikansi 0,05 yakni sebesar 1,6820 maka thitung lebih rendah daripada $t_{\text {tabel }}(1,666<1,6820)$. Nilai probabilitas signifikansi sebesar 0,104 menunjukkan nilai yang lebih besar dari nilai pada tingkat signifikansi yang telah ditentukan sebelumnya yakni 0,05 (0,104 > 0,05). Berdasarkan hasil uji hipotesis tersebut maka dapat disimpulkan bahwa variabel Kepemilikan Manajerial (MNJR) memiliki pengaruh positif tetapi tidak signifikan terhadap Kebijakan Dividen (DPR).

Hasil penelitian ini sesuai dengan hasil penelitian Imanda Firmantyas Putri dan Mohammad Nasir (2006) serta Kartika 


\section{JURNAL NOMINAL / VOLUME IV NOMOR 1 / TAHUN 2015}

Nuringsih (2005). Hasil penelitian tersebut memberi kesimpulan bahwa tingkat Kepemilikan Manajerial yang tinggi akan menyebabkan aset yang dimiliki tidak terdiversifikasi secara optimal sehingga manajerial menginginkan return atas opportunity cost yang besar yaitu dengan pembagian dividen yang semakin besar. Selain itu, struktur kepemilikan perusahaan di Indonesia relatif terkonsentrasi atau dikuasai oleh keluarga sehingga cenderung membagikan dividen yang lebih besar. Sebaliknya, perusahaan yang memiliki Kepemilikan Manajerial rendah menunjukkan diversifikasi yang optimal sehingga cenderung lebih menyukai retained earning dan kemudian akan membayar dividen dalam jumlah yang rendah.

\section{Hasil Uji Hipotesis Kedua}

Tabel 8. Ringkasan Hasil Uji Hipotesis Kedua

\begin{tabular}{cccccc}
\hline Varia- & Kons- & Koe- & $\mathrm{r}^{2}$ & $\mathrm{t}_{\text {hitung }}$ & Sig. \\
bel & tanta & fisien & & &
\end{tabular}

$$
\text { Re- }
$$$$
\text { gresi }
$$

\begin{tabular}{llllll}
\hline INST & 0,190 & 0,400 & 0,094 & 2,035 & 0,048
\end{tabular}

Berdasarkan tabel 8 di atas, persamaan regresi sebagai berikut:

$\mathrm{DPR}=0,190+0,400 \mathrm{INST}$
Berdasarkan tabel 8 dapat dilihat bahwa nilai thitung sebesar 2,035 jika dibandingkan dengan $t_{\text {tabel }}$ pada tingkat signifikansi 0,05 yakni sebesar 1,682 maka thitung lebih tinggi daripada $t_{\text {tabel }}(2,035>1,6820)$. Nilai probabilitas signifikansi sebesar 0,048 menunjukkan nilai yang lebih kecil dari nilai pada tingkat signifikansi yang telah ditentukan sebelumnya yakni $0,05(0,048 \leq$ 0,05). Berdasarkan hasil uji hipotesis tersebut maka dapa disimpulkan bahwa variabel Kepemilikan Institusional (INST) memiliki pengaruh positif dan signifikan terhadap Kebijakan Dividen (DPR).

Hasil penelitian ini sesuai dengan hasil penelitian Thanatawee, Yordying (2012). Hasil penelitian tersebut mengambil kesimpulan bahwa Kepemilikan Institusional berpengaruh positif dan signifikan terhadap Kebijakan Dividen. Semakin besar kepemilikan saham institusional maka Kebijakan Dividen yang ditetapkan akan semakin besar. Keberadaan pemilik institusional diharapkan mampu melaksanakan fungsi monitoring yang efektif terhadap manajemen perusahaan. Fungsi monitoring tersebut bertujuan agar manajemen bertindak dengan tujuan mementingkan kemakmuran para pemegang saham, bukan mengutamakan kepentingannya dan bertindak oportunistik. Kepemilikan Institusional yang besar mampu mendorong manajerial perusahaan untuk bertindak selaras dengan kepentingan 


\section{JURNAL NOMINAL / VOLUME IV NOMOR 1 / TAHUN 2015}

pemegang saham yakni dengan pembagian dividen yang besar pula. Selain itu, pembayaran dividen dapat dikatakan efektif sebagai insentif dari upaya monitoring yang telah dilaksanakan pemilik insitusional terhadap manajemen perusahaan.

\section{Hasil Uji Hipotesis Ketiga}

Tabel 9. Ringkasan Hasil Uji Hipotesis Ketiga

\begin{tabular}{cccccc}
\hline Varia & Kons- & Koe- & $\mathrm{r}^{2}$ & thitung & Sig. \\
bel & tanta & fisien & & & \\
& & Re- & & \\
& & gresi & & \\
& & & &
\end{tabular}

\begin{tabular}{llllll}
\hline CAPB & 0,524 & $-1,003$ & 0,096 & $-2,058$ & 0,046
\end{tabular} VA

Berdasarkan tabel 9 di atas, persamaan regresi sebagai berikut:

$\mathrm{DPR}=0,524-1,003 \mathrm{CAPBVA}$

Berdasarkan tabel 9 dapat dilihat bahwa nilai $t_{\text {hitung }}$ sebesar -2,058 jika dibandingkan dengan tabel pada tingkat signifikansi 0,05 yakni sebesar -1,682 maka thitung lebih rendah daripada $t_{\text {tabel }}(-2,058 \leq-1,6820)$. Nilai probabilitas signifikansi sebesar 0,046 menunjukkan nilai yang lebih kecil dari nilai pada tingkat signifikansi yang telah ditentukan sebelumnya yakni 0,05 $(0,046 \leq$ 0,05). Berdasarkan hasil uji hipotesis tersebut maka dapat disimpulkan bahwa variabel Kesempatan Investasi (CAPBVA) memiliki pengaruh negatif dan signifikan terhadap Kebijakan Dividen (DPR).

Hasil penelitian ini selaras dengan hasil penelitian Marpaung, Elyzabet Indrawati dan Bram Hadianto (2009) serta Titik Suwarti (2010). Hasil penelitian tersebut memberi kesimpulan bahwa Kesempatan Investasi tidak semata-mata hanya ditunjukkan dengan adanya proyek-proyek yang didukung oleh riset dan pengembangan saja, tetapi juga dengan kemampuan perusahaan yang lebih dalam mengeksploitasi kesempatan mengambil keuntunggan dibandingkan dengan perusahaan lain yang setara dalam satu kelompok industri. Perusahaan yang memiliki Kesempatan Investasi yang tinggi akan membutuhkan dana yang besar pula. Kebutuhan dana tersebut dapat diperoleh dari sumber dana internal dan eksternal. Pemenuhan kebutuhan dana investasi yang dibiayai dari sumber internal perusahaan akan berdampak pada penurunan pembayaran dividen dalam kaitannya dengan Kebijakan Dividen. 
JURNAL NOMINAL / VOLUME IV NOMOR 1 / TAHUN 2015

Hasil Uji Hipotesis Keempat

Tabel 10. Ringkasan Hasil Uji Hipotesis Keempat

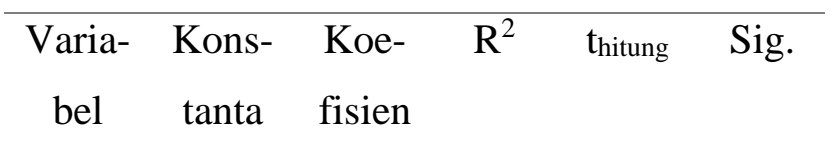

Re-

gresi

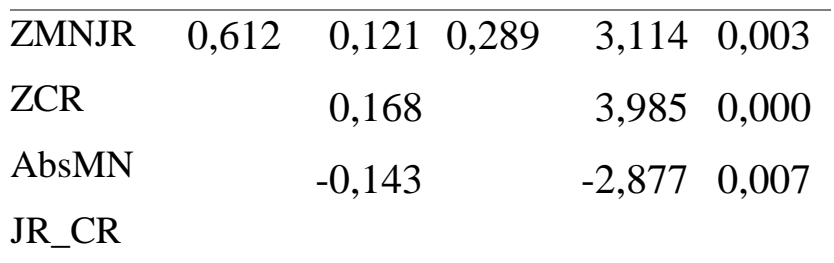

Berdasarkan tabel 10 di atas, persamaan regresi sebagai berikut:

$\mathrm{DPR}=0,612+0,121 \mathrm{MNJR}+0,168 \mathrm{CR}-$ 0,143 |MNJR-CR|

Berdasarkan tabel 10 dapat dilihat bahwa nilai $t_{\text {hitung }}$ variabel interaksi antara Kepemilikan Manajerial dan Likuiditas (AbsMNJR_CR) $\quad$ sebesar $\quad-2,877$ jika dibandingkan dengan $t_{\text {tabel }}$ pada tingkat signifikansi 0,05 (uji 2 sisi) yakni sebesar 2,0181 maka $t$ hitung lebih rendah daripada $\mathrm{t}_{\text {tabel }}(-2,877 \leq 2,0181)$. Nilai probabilitas signifikansi variabel interaksi antara Kepemilikan Manajerial dan Likuiditas $\begin{array}{lll}\text { (AbsMNJR_CR) } \quad \text { sebesar } & 0,007\end{array}$ menunjukkan nilai yang lebih kecil dari nilai pada tingkat signifikansi yang telah ditentukan sebelumnya yakni $0,05(0,007 \leq$ 0,05). Berdasarkan hasil uji hipotesis maka dapat disimpulkan bahwa variabel Likuiditas mampu memoderasi pengaruh
Kepemilikan Manajerial terhadap Kebijakan Dividen.

Kepemilikan Manajerial lebih memprioritaskan laba pada laba ditahan dibandingkan untuk membayar dividen. Hal tersebut karena alasan keefektifan penggunaan dana internal dibandingkan dana eksternal. Terlebih jika memiliki Likuiditas yang baik, pihak manajemen perusahaan akan menggunakan potensi Likuiditas yang ada untuk melunasi utang atau mendanai operasi perusahaan. Oleh karena itu, manajemen tidak perlu khawatir akan adanya peningkatan financial distress dan kebangkrutan akibat penggunaan utang tinggi karena baik operasi maupun investasi dapat dibiayai dengan potensi Likuiditas yang ada. Dengan demikian, Likuiditas mampu memoderasi pengaruh Kepemilikan Manajerial terhadap Kebijakan Dividen.

\section{Hasil Uji Hipotesis Kelima}

Tabel 11. Ringkasan Hasil Uji Hipotesis Kelima

\begin{tabular}{lccccc}
\hline $\begin{array}{l}\text { Varia- } \\
\text { bel }\end{array}$ & $\begin{array}{c}\text { Kons- } \\
\text { tanta }\end{array}$ & $\begin{array}{c}\text { Koe- } \\
\text { fisien } \\
\end{array}$ & $\mathrm{R}^{2}$ & $\mathrm{t}_{\text {hitung }}$ & Sig. \\
& \multicolumn{5}{c}{ Re- } \\
& & & \\
& & & & \\
\hline Zresi & & & \\
ZCR & 0,670 & 0,059 & 0,332 & 1,839 & 0,074 \\
AbsIN & & 0,122 & 3,785 & 0,001 \\
ST_CR & & $-0,158$ & $-3,133$ & 0,003 \\
& & & & &
\end{tabular}




\section{JURNAL NOMINAL / VOLUME IV NOMOR 1 / TAHUN 2015}

Berdasarkan tabel 11 di atas, persamaan regresi sebagai berikut:

$\mathrm{DPR}=0,670+0,059 \mathrm{INST}+0,122 \mathrm{CR}-$ 0,158 |INST-CR|

Berdasarkan tabel 11 dapat dilihat bahwa nilai $t_{\text {hitung }}$ variabel interaksi antara Kepemilikan Institusional dan Likuiditas (AbsINST_CR) $\quad$ sebesar $\quad-3,133$ jika dibandingkan dengan $t_{\text {tabel }}$ pada tingkat signifikansi 0,05 (uji 2 sisi) yakni sebesar 2,0181 maka $t_{\text {hitung }}$ lebih kecil daripada $t_{\text {tabel }}$ $(-3,133<-2,0181)$. Nilai probabilitas signifikansi variabel interaksi antara Kepemilikan Institusional dan Likuiditas (AbsINST_CR) sebesar 0,003 menunjukkan nilai yang lebih kecil dari nilai pada tingkat signifikansi yang telah ditentukan sebelumnya yakni $0,05 \quad(0,003 \leq 0,05)$. Berdasarkan hasil uji hipotesis maka dapat disimpulkan bahwa variabel Likuiditas mampu memoderasi pengaruh Kepemilikan Institusional terhadap Kebijakan Dividen.

Adanya Kepemilikan Institusional akan memiliki dampak dalam perusahaan termasuk dalam hal Kebijakan Dividen. Tingginya Kepemilikan Institusional akan menekan manajerial untuk mensejahterakan dan mengutamakan kepentingannya yakni mendapatkan dividen dalam jumlah yang besar. Posisi Likuiditas perusahaan merupakan faktor penting yang harus dipertimbangkan sebelum mengambil keputusan untuk menetapkan besarnya dividen yang akan dibayarkan kepada pemegang saham. Oleh karena dividen merupakan arus kas keluar maka semakin kuat posisi Likuiditas perusahaan akan semakin tinggi kemampuan perusahaan untuk membayar dividen. Oleh karena itu, Likuiditas mampu memoderasi hubungan positif antara Kepemilikan Institusional dan Kebijakan Dividen.

\section{Hasil Uji Hipotesis Keenam}

Tabel 12. Ringkasan Hasil Uji Hipotesis Keenam

\begin{tabular}{lccccc}
\hline $\begin{array}{c}\text { Varia- } \\
\text { bel }\end{array}$ & $\begin{array}{c}\text { Kons- } \\
\text { tanta }\end{array}$ & $\begin{array}{c}\text { Koe- } \\
\text { fisien } \\
\text { Re- }\end{array}$ & $\mathrm{R}^{2}$ & thitung & Sig. \\
& & & & \\
& & gresi & & \\
& & & & \\
\hline ZCAPB & 0,586 & 0,079 & 0,214 & 1,306 & 0,307 \\
VA & & 0,153 & 2,699 & 0,010 \\
ZCR & & $-0,103$ & $-1,557$ & 0,128
\end{tabular}

AbsCA

PBVA

CR

Berdasarkan tabel 12 di atas, persamaan regresi sebagai berikut:

$\mathrm{DPR}=0,586+0,079 \mathrm{CAPBVA}+0,153 \mathrm{CR}$ - 0,103 |CAPBVA-CR|

Berdasarkan tabel 12 dapat dilihat bahwa nilai $t_{\text {hitung }}$ variabel interaksi antara Kesempatan Investasi dan Likuiditas (AbsCAPBVA_CR) sebesar -1,557 jika dibandingkan dengan $t_{\text {tabel }}$ pada tingkat signifikansi 0,05 (uji 2 sisi) yakni sebesar 2,0181 maka $t_{\text {hitung }}$ lebih tinggi daripada $t_{\text {tabel }}$ 


\section{JURNAL NOMINAL / VOLUME IV NOMOR 1 / TAHUN 2015}

$(-1,557>-2,0181) . \quad$ Nilai probabilitas signifikansi variabel interaksi antara Kesempatan Investasi dan Likuiditas (AbsINST_CR) sebesar 0,128 menunjukkan nilai yang lebih besar dari nilai pada tingkat signifikansi yang telah ditentukan sebelumnya yakni $0,05(0,128>0,05)$. Berdasarkan hasil uji hipotesis maka dapat disimpulkan bahwa variabel Likuiditas tidak mampu memoderasi pengaruh Kesempatan Investasi terhadap Kebijakan Dividen.

Hasil penelitian ini selaras dengan penelitian Titiek Suwarti (2010) yang menjelaskan bahwa Likuiditas tidak mampu memperkuat pengaruh Kesempatan Investasi terhadap Kebijakan Dividen. Hasil penelitian ini tidak sesuai dengan penelitian Michell Suharli (2007) yang menjelaskan bahwa likuiditas mampu memperkuat pengaruh Kesempatan Investasi terhadap Kebijakan Dividen. Likuiditas diartikan sebagai kemampuan melunasi seluruh kewajiban jangka pendeknya dan mendanai operasionalnya. Perusahaan yang memiliki Likuiditas lebih baik maka akan mampu membayar dividen lebih banyak. Pada perusahaan yang menggunakan dana untuk investasi lebih banyak akan menyebabkan dana untuk pembayaran dividen berkurang. Likuiditas yang baik mampu meminimalisir keadaan tersebut karena saat itu perusahaan dapat menunda pembayaran hutang jangka pendeknya. Dengan demikian, perusahaan yang memiliki Likuiditas baik mampu memanfaatkan Kesempatan Investasi serta mampu membayarkan dividen dalam jumlah yang tinggi.

\section{Hasil Uji Hipotesis Ketujuh}

Tabel 13. Ringkasan Hasil Uji Hipotesis Ketujuh

\begin{tabular}{lccccc}
\hline $\begin{array}{l}\text { Varia- } \\
\text { bel }\end{array}$ & Kons- & Koe- & $\mathrm{R}^{2}$ & $\mathrm{~F}_{\text {hitung }}$ & Sig. \\
& tanta & $\begin{array}{c}\text { fisien } \\
\text { Re- }\end{array}$ & & & \\
& & & & \\
& & gresi & & & \\
MNJR & 0271 & 1,066 & 0,199 & 3,156 & 0,036 \\
INST & & 0,309 & & & \\
CAPB & & $-0,840$ & & & \\
VA & & & & & \\
\hline
\end{tabular}

Berdasarkan tabel 13 di atas, persamaan regresi sebagai berikut:

$\mathrm{DPR}=0,271+1,066 \mathrm{MNJR}+0,309 \mathrm{INST}$ -

\section{0,840 CAPBVA}

Berdasarkan tabel 13 dapat diketahui bahwa nilai $F$ hitung sebesar 3,156 dengan probabilitas 0,036 menunjukkan nilai yang lebih rendah dari nilai pada tingkat signifikansi yang telah ditentukan sebelumnya yakni $0,05 \quad(0,036 \leq 0,05)$. Dengan nilai probabilitas yang lebih kecil dari tingkat signifikansi tersebut maka model regresi ini dapat digunakan untuk memprediksi Kebijakan Dividen (DPR).

Berdasarkan hasil uji hipotesis maka dapat disimpulkan bahwa Kepemilikan Manajerial (MNJR), Kepemilikan Institusional (INST), 


\section{JURNAL NOMINAL / VOLUME IV NOMOR 1 / TAHUN 2015}

dan Kesempatan Investasi (CAPBVA) secara bersama-sama berpengaruh terhadap Kebijakan Dividen (DPR).

Peningkatan Kepemilikan Manajerial akan menyetarakan kepentingannya dengan pemegang saham sehingga dapat bekerja lebih hati-hati karena keputusan yang diambil pada nantinya mereka juga akan merasakan dampaknya. Kinerja manajer akan selalu diawasi oleh investor institusional. Investor institusional akan melakukan fungi monitoring agar manajemen perusahaan bekerja untuk tujuan memakmurkan pemegang saham dan investor institusional juga mengaharapkan dividen yang tinggi sebagai return atas pengorbananya menanamkan saham di perusahaan. Selain itu, dividen dianggap sebagai insentif atas fungsi monitoring yang telah dilakukannya.

\section{SIMPULAN DAN SARAN}

\section{Simpulan}

a. Kepemilikan Manajerial berpengaruh positif tetapi tidak signifikan terhadap Kebijakan Dividen pada perusahaan sektor industri barang konsumsi yang terdaftar di Bursa Efek Indonesia periode 2008-2013. Hal ini ditunjukkan dengan Berdasarkan tabel 30 dapat dilihat bahwa nilai $t_{\text {hitung }}$ sebesar 1,666 jika dibandingkan dengan tabel pada tingkat signifikansi 0,05 yakni sebesar 1,6820 maka $t_{\text {hitung }}$ lebih rendah daripada $t_{\text {tabel }}$
$(1,666<1,6820)$. Nilai probabilitas signifikansi sebesar 0,104 menunjukkan nilai yang lebih besar dari nilai pada tingkat signifikansi yang telah ditentukan sebelumnya yakni $0,05(0,104>0,05)$. Oleh karena itu, dapat disimpulkan bahwa Kepemilikan Manajerial (MNJR) memiliki pegaruh positif dan tidak signifikan terhadap Kebijakan Dividen (DPR).

b. Kepemilikan Institusional berpengaruh positif dan signifikan terhadap Kebijakan Dividen pada perusahaan sektor industri barang konsumsi yang terdaftar di Bursa Efek Indonesia periode 2008-2013. Berdasarkan tabel 31 dapat dilihat bahwa nilai thitung sebesar 2,035 jika dibandingkan dengan $t_{\text {tabel }}$ pada tingkat signifikansi 0,05 yakni sebesar 1,682 maka $t_{\text {hitung }}$ lebih tinggi daripada $t_{\text {tabel }}$ $(2,035 \geq 1,6820)$. Nilai probabilitas signifikansi sebesar 0,048 menunjukkan nilai yang lebih kecil dari nilai pada tingkat signifikansi yang telah ditentukan sebelumnya yakni $0,05(0,048 \leq 0,05)$. Oleh karena itu, dapat disimpulkan bahwa Kepemilikan Institusional (INST) memiliki pegaruh positif dan signifikan terhadap Kebijakan Dividen (DPR).

c. Kesempatan Investasi berpengaruh negatif dan signifikan terhadap Kebijakan Dividen pada perusahaan sektor industri barang konsumsi yang terdaftar di Bursa Efek Indonesia periode 2008-2013. 


\section{JURNAL NOMINAL / VOLUME IV NOMOR 1 / TAHUN 2015}

Berdasarkan tabel 32 dapat dilihat bahwa nilai thitung sebesar $-2,058$ jika dibandingkan dengan $t_{\text {tabel }}$ pada tingkat signifikansi 0,05 yakni sebesar $-1,682$ maka thitung lebih rendah daripada $t_{\text {tabel }}(-$ $2,058 \leq-1,6820)$. Nilai probabilitas signifikansi sebesar 0,046 menunjukkan nilai yang lebih kecil dari nilai pada tingkat signifikansi yang telah ditentukan sebelumnya yakni $0,05(0,046 \leq 0,05)$.

d. Likuiditas mampu memoderasi pengaruh Kepemilikan Manajerial terhadap Kebijakan Dividen terhadap Kebijakan Dividen pada perusahaan sektor industri barang konsumsi yang terdaftar di Bursa Efek Indonesia periode 2008-2013. Berdasarkan tabel 33 dapat diketahui bahwa nilai t hitung variabel interaksi antara Kepemilikan Manajerial dan Likuiditas (AbsMNJR_CR) sebesar 2,877 jika dibandingkan dengan tabel pada tingkat signifikansi 0,05 (uji 2 sisi) yakni sebesar -2,0181 maka $\mathrm{t}$ hitung lebih rendah daripada tabel $(-2,877 \leq$ 2,0181). Nilai probabilitas signifikansi variabel interaksi antara Kepemilikan Manajerial dan Likuiditas (AbsMNJR_CR) sebesar $\quad 0,007$ menunjukkan nilai yang lebih kecil dari nilai pada tingkat signifikansi yang telah ditentukan sebelumnya yakni $0,05(0,007$ $\leq 0,05)$.

e. Likuiditas mampu memoderasi pengaruh Kepemilikan Institusional terhadap
Kebijakan Dividen terhadap Kebijakan Dividen pada perusahaan sektor industri barang konsumsi yang terdaftar di Bursa Efek Indonesia periode 2008-2013. Berdasarkan tabel 34 dapat diketahui bahwa nilai thitung variabel interaksi antara Kepemilikan Institusional dan Likuiditas (AbsINST_CR) sebesar -3,133 jika dibandingkan dengan $t_{\text {tabel }}$ pada tingkat signifikansi 0,05 (uji 2 sisi) yakni sebesar -2,0181 maka $t_{\text {hitung }}$ lebih kecil daripada $t_{\text {tabel }}(-3,133 \leq-2,0181)$. Nilai probabilitas signifikansi variabel interaksi antara Kepemilikan Institusional dan Likuiditas (AbsINST_CR) $\quad$ sebesar $\quad 0,003$ menunjukkan nilai yang lebih kecil dari nilai pada tingkat signifikansi yang telah ditentukan sebelumnya yakni $0,05(0,003$ $\leq 0,05)$.

f. Likuiditas mampu memoderasi pengaruh Kesempatan Invetsasi terhadap Kebijakan Dividen terhadap Kebijakan Dividen pada perusahaan sektor industri barang konsumsi yang terdaftar di Bursa Efek Indonesia periode 2008-2013. Berdasarkan tabel 35 menunjukkan bahwa nilai $t_{\text {hitung }}$ variabel interaksi antara Kesempatan Investasi dan Likuiditas (AbsCAPBVA_CR) sebesar -1,557 jika dibandingkan dengan $t_{\text {tabel }}$ pada tingkat signifikansi 0,05 (uji 2 sisi) yakni sebesar -2,0181 maka thitung lebih tinggi daripada $t_{\text {tabel }}(-1,557>-2,0181)$. Nilai probabilitas signifikansi variabel interaksi antara 
JURNAL NOMINAL / VOLUME IV NOMOR 1 / TAHUN 2015

Kesempatan Investasi dan Likuiditas (AbsINST_CR) $\quad$ sebesar $\quad 0,128$ menunjukkan nilai yang lebih besar dari nilai pada tingkat signifikansi yang telah ditentukan sebelumnya yakni $0,05(0,128$ $>0,05)$.

g. Kepemilikan Manajerial, Kepemilikan Institusional, dan Kesempatan Investasi berpengaruh bersama-sama terhadap Kebijakan Dividen. Berdasarkan tabel 36 dapat diketahui bahwa nilai $\mathrm{F}$ hitung sebesar 3,156 dengan probabilitas 0,036 menunjukkan nilai yang lebih rendah dari nilai pada tingkat signifikansi yang telah ditentukan sebelumnya yakni $0,05(0,036$ $\leq 0,05)$.

\section{Saran}

a. Bagi investor

Investor harus bijak dalam memutuskan investasi di suatu perusahaan. Beberapa hal yang dapat dipertimbangkan adalah terkait dengan persentase Kepemilikan Institusional dalam perusahaan yang dituju karena berdasarkan hasil penelitian ini, semakin besar kepemilikan institusional semakin besar pula kebijakan dividennya. Pertimbangan kedua adalah Kesempatan Investasi yang dimiliki perusahaan, berdasarkan hasil penelitian ini semakin besar kesempatan investasi maka semakin kecil kebijakan dividennya. Pertimbangan ketiga adalah Likuiditas, investor hendaknya mempertimbangkan posisi likuiditas perusahaan karena posisi likuiditas yang baik menunjukkan bahwa perusahaan mampu mengelola keuangannya dengan baik.

b. Bagi perusahaan

1) Perusahaan hendaknya mampu mempertahankan dan meningkatkan kinerjanya sehingga mendapat loyalitas investor institusional serta menarik minat investor institusional lainnya. Dengan demikian, diharapkan pembayaran dividen akan tetap tinggi.

2) Perusahaan hendaknya mampu memilih Kesempatan Investasi yang tepat sehingga dana yang dikeluarkan dapat optimal. Dengan kebijakan tersebut, diharapkan perusahaan tetap mampu membayarkan dividen kepada pemegang saham karena pengelolaan dana yang baik.

c. Bagi peneliti selanjutnya

1) Peneliti selanjutnya sebaiknya melakukan penelitian serupa namun dengan sektor yang berbeda dan dengan jumlah sampel yang lebih banyak sehingga mampu memperkuat hasil penelitian-penelitian yang telah dilakukan sebelumnya.

2) Penelitian ini hanya menggunakan satu proksi dari Kesempatan Investasi yaitu Capital Expenditure to Market Value of Asset (CAPBVA). Oleh karena itu, peneliti selanjutnya 


\section{JURNAL NOMINAL / VOLUME IV NOMOR 1 / TAHUN 2015}

diharapkan dapat menggunakan proksi lain seperti Market to Book Value of Equity Ratio (MBVE), Market to Book Value of Asset Ratio (MBVA), Price to Earning Ratio (PER), Property, Plant, and Equipment to Book Value of Asset Ratio (PPEBVA), Capital Expenditure to Market Value Asset (CAPMVA), Current Assets to Net Sales (CAONS), atau Variance of Total Return (VARRET) agar dapat lebih menggambarkan variabel Kesempatan Investasi.

3) Penelitian ini hanya menggunakan Likuiditas sebagai variabel pemoderasi. Oleh karena itu, peneliti selanjutnya diharapkan dapat menggunakan variabel lain seperti leverage agar mendapatkan hasil yang lebih beragam lagi.

\section{DAFTAR PUSTAKA}

Brigham, E.F. dan Houston, J.F. (2011). Dasar-Dasar Manajemen Keuangan. (Alih Bahasa: Ali Akbar Yulianto). Jakarta: Salemba Empat.

Ratih Fitria Sari. (2010). “Analisis Pengaruh Kepemilikan Manajerial, Kebijakan Utang, Profitabilitas, Ukuran Perusahaan, dan Kesempatan Investasi terhadap Kebijakan Dividen”. Skripsi. Universitas Sebelas Maret.
Sisca Christianty Dewi. (2008). "Pengaruh Kepemilikan Manajerial, Kepemilikan Institusional, Kebijakan Utang, Profitabilitas, dan Ukuran Perusahaan terhadap Kebijakan Dividen”. Jurnal Bisnis dan Akuntansi, 10(1), hlm. 4758.

Jensen, M.C. dan Meckling, W.H. (1976). "Theory of the Firm: Managerial Behavior, Agency Costs and Ownership Structure". Journal of Financial Economics, 3(4), pp. 305-360.

Shleifer, Andrei dan Vishny, Robert N. (1986). "The Journal of Political Economy”, 94(3), pg. 461-488.

Kartika Nuringsih. (2005). “Analisis Pengaruh Kepemilikan Manajerial, Kebijakan Utang, ROA, dan Ukuran Perusahaan terhadap Kebijakan Dividen: Studi 1995-1996". Jurnal Akuntansi dan Keuangan Indonesia, 2(2), hlm. 103-123.

Michell Suharli dan Megawati Oktorina. (2005). "Memprediksi Tingkat Pengembalian Investasi pada Equity Securities Melalui Rasio Profitabilitas, Likuiditas, dan Hutang pada Perusahaan Publik di Jakarta”. Simposium Nasional Akuntansi VIII Solo, hlm. 288-296.

Michell Suharli. (2007). "Pengaruh Profitability dan Investment Opportunity Set terhadap Kebijakan Dividen Tunai dengan Likuiditas sebagai Variabel Penguat". Jurnal 
Akuntansi dan Keuangan, 9(1), hlm. 917.

Van Horne, James C dan Wachowicz, John M. (2007). Prinsip-Prinsip Manajemen Keuangan Edisi 12. Jakarta: Salemba Empat.

Indriantoro, N. dan Supomo, B. (2002). Metodologi Penelitian Bisnis. Yogyakarta: BPFE-Yogyakarta.

Thanatawee, Yordying. (2013). “Ownership Structure and Dividend Policy: Evidence from Thailand". International Journal of Economics and Finance, 5(1), pg. 121-131.

Imanda Firmantyas Putri dan Mohammad Nasir. (2006). “Analisis Persamaan Simultan Kepemilikan Manajerial, Kepemilikan Institusional, Risiko, Kebijakan Utang, dan Kebijakan Dividen dalam Perspektif Teori Keagenan. Simposium Nasional Akuntansi IX Padang.

Elyzabet Indrawati Marpaung dan Bram Hadianto. (2009). PPengaruh Profitabilitas dan Kesempatan Investasi terhadap Kebijakan Dividen: Studi empiric pada Emiten Pembentuk Indeks LQ45 di Bursa Efek Indonesia. Jurnal Akuntansi 1(1), hlm. 70-84. 